Received: June 2, 2017

Revision received: March 21, 2018

\title{
Research on the Innovation of College Students' Ideological and Political Education based on the Synergetics Theory
}

\author{
Jianhong Miao $^{1}$ \\ Weizhi $\mathrm{Tao}^{2}$ \\ Yong $\mathrm{Qi}^{3}$ \\ Nanjing University of Science and \\ Nanjing University of \\ Nanjing University of Science \\ Technology \\ Science and Technology \\ and Technology
}

\begin{abstract}
The development of ideological and political education for college students is inseparable from the innovation of educational methods. In various innovate methods, the application of theories of some emerging disciplines as reference is a common way to guide the innovation. The introduction of the synergetics theory to the ideological and political education of college students can promote the full integration of various elements related to ideological education, which has very important practical significance for the innovation of ideological and political education of college students. At present, college students' ideological and political education is challenged by problems such as diversified beliefs, differences in values, and lack of collective consciousness. This paper, by drawing on the basic methods in the synergetics theory, established an innovative model of ideological and political education, namely the open synergistic teaching method, including ideological information forecasting method, cognitive load coordination teaching method, ideological and political education decision-making method, and ideological and political education implementation feedback method. The method has universal applicability and can better realize the ultimate goal of college students' ideological and political education.
\end{abstract}

\section{Keywords}

Synergetics Theory • College Students' Ideological and Political Education • Innovation

\footnotetext{
*Postgraduate Education Reform Project of Jiangsu Province, Research on Cultivation of Postgraduates' Innovation Ability based on Innovation Chain, JGZZ15_021

${ }^{1}$ Correspondence to: Jianhong Miao (PhD), School of Science, Nanjing University of Science and Technology, Nanjing 210000, China. Email: 21478888@ sina.com

${ }^{2}$ School of Science, Nanjing University of Science and Technology, Nanjing 210000, China. Email: taoweizhi@ njust.edu.cn

${ }^{3}$ School of Science, Nanjing University of Science and Technology, Nanjing 210000, China. Email: qyong@ just.edu.cn
}

Citation: Miao, J.H., Tao, W.Z., \& Qi, Y. (2018). Research on the Innovation of College Students' Ideological and Political Education based on the Synergetics Theory. Educational Sciences: Theory \& Practice, 18(5), 2478-2485. http://dx.doi.org/10.12738/estp.2018.5.148 
At present, the continuous social development and the ever-changing environment at home and abroad have a profound impact on the traditional ideological and political education of college students. The development of ideological and political education for college students is inseparable from the innovation of educational methods, while the introduction of the theories of some emerging disciplines as reference to guide the innovation is a common method among various innovation methods (Paton, 2012). The synergetics theory, originating in the late 1970s, is a discipline mainly on the synergy between multiple subsystems in the system. It has a significant influence on researches in many fields, as well as the ideological and political education of college students, attracting the attention of many educators ( $\mathrm{Hu}, 2011)$. The application of the synergetics theory into the ideological and political education of college students can not only accurately uphold the direction of ideological and political education of college students, but also promote the full integration of various elements related to ideological education, which is of important practical significance to the innovation and quality improvement of ideological and political education for college students (Somerville, 2014).

Many experts and scholars at home and abroad have done a lot of researches on the innovation of college students' ideological and political education with many research results, but there are also some shortcomings in that they mainly focused on macroscopic discussion but in a lack of description of methods (Higgs, 1996). This paper mainly drew on the relevant theories of synergetics to innovate the ideological and political education for college students. It has universal applicability and can better realize the ultimate goal of ideological and political education for college students, for which this paper embodies certain innovation and practical significance.

\section{The Status Quo of College Students' Ideological and Political Education}

\section{Belief Diversification}

At present, with the social development and the technological advancement, there are more and more methods and channels for college students to access outside information. In the process of continuous formation of world outlook and values, they are easily influenced by foreign thoughts. College students in the past believed in Marxism, but nowadays college students are more inclined to Western thoughts with diversified beliefs.

\section{Different Values}

At present, the dominant values of college students have changed a lot. For example, in a survey on "What are you most concerned about", more than $90 \%$ of students cared about their future, family, work, etc., while only a few college students cared about major events of the country. It shows that today's college students pay more attention to personal gains and losses, and their ideological and political consciousness has not reached the country level. 


\section{Lack of Collective Consciousness}

The current college students are basically born after 1990 as the only child, resulting in the prevalence of self-centeredness. They do not understand how to respect others and lack collective consciousness.

\section{Establishment of the Synergistic Teaching Model}

The core issue of the synergetics theory is the change of the system in macroscopic characteristics. The relationship between the microelements and the macro-features in the system is studied. In the whole system, the high-dimensional problem is transformed into a low-dimensional problem to be handled. The specific process is shown in Figure 1.

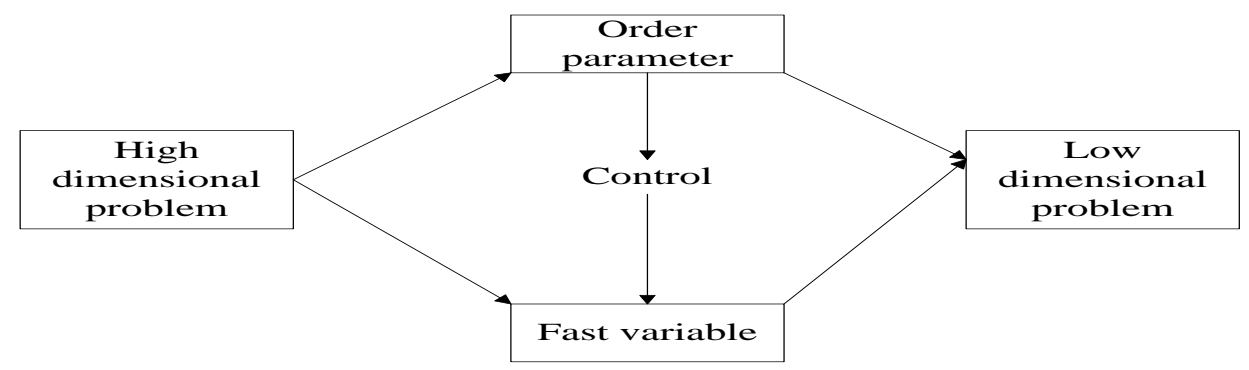

Figure 1. Schematic diagram of synergetic method for dealing with problems.

The analysis of ideological and political education methods through the synergetics theory is mainly to transform high-dimensional problems to low-dimensional problems. Firstly, the order parameters should be set. The main purpose of the ideological and political education method is to promote the effective development of ideological and political education activities. There are four aspects that will affect the ideological and political education methods, mainly: educators, educatees, environmental conditions, and development conditions. The first three aspects will have an important impact on the innovation of ideological and political education methods. They all correspond to a prototype vector, and the relationship among them is shown in Figure 2.

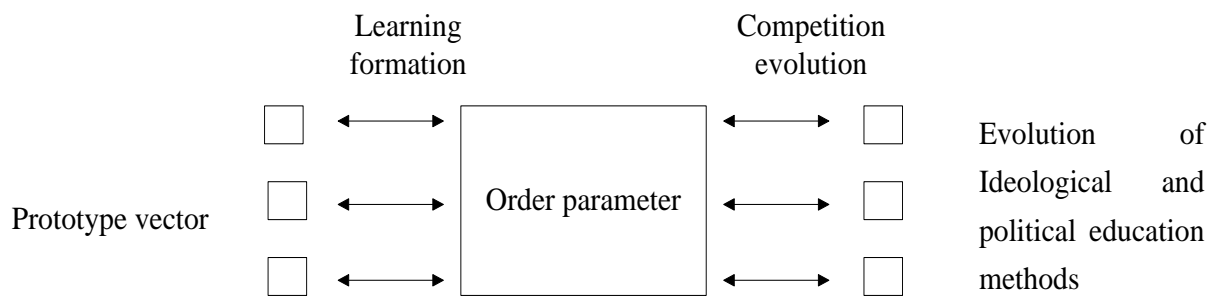

Figure 2. Relationship between prototype vectors and ordinal parameters in Ideological and political education method system.

In this paper, an innovative model of ideological and political education based on the synergetics theory was established, namely the open synergistic teaching method. It includes the synergy between ideological and political education methods and the external environment including information, energy and material, as well as ideological information forecasting method, cognitive load coordination teaching method, ideological and 
political education decision-making method, and ideological and political education implementation feedback method. Details are shown in Figure 3.

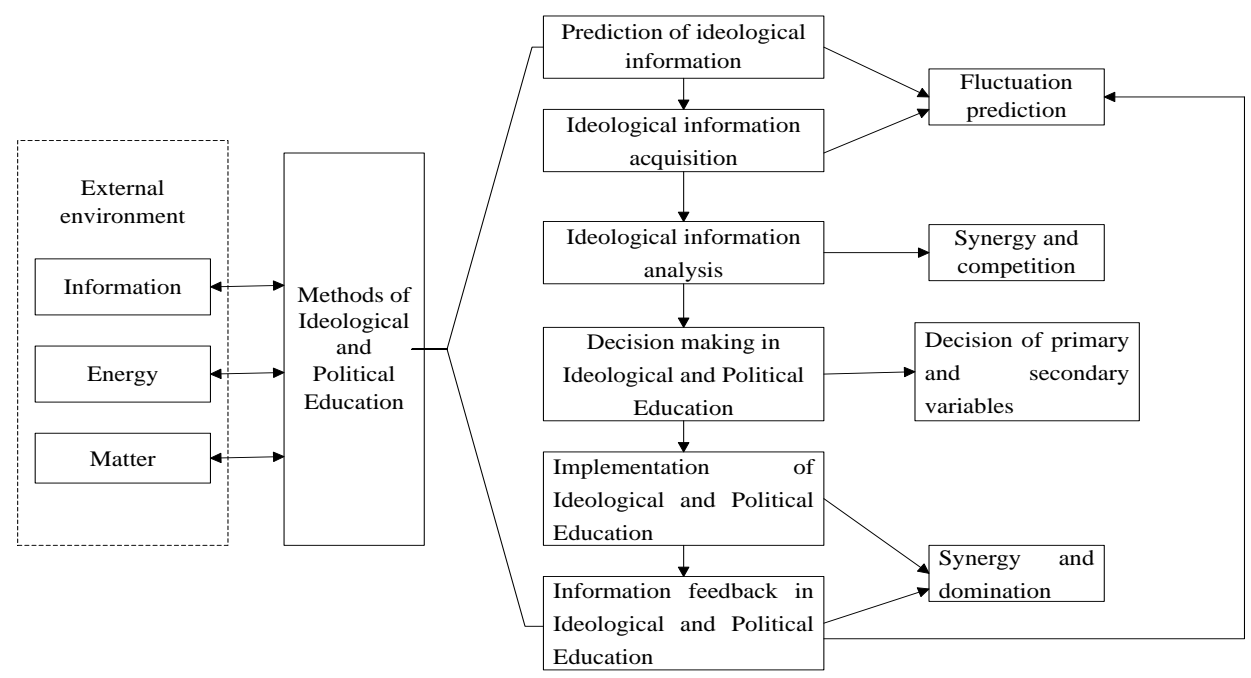

Figure 3. Structure of the open synergistic teaching method model.

\section{Innovation of College Students' Ideological and Political Education}

\section{Ideological Information Forecasting}

It is difficult to predict the ideological information to certain extent. Generally, the basic process is shown in Figure 4.

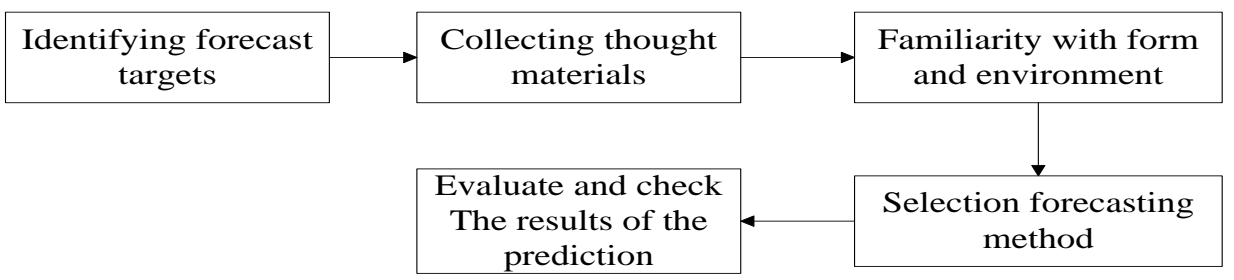

Figure 4. The basic process of thought prediction.

In this process, the educator should comprehensively observe the detailed changes in the thoughts and actions of the educated, and make predictions on the ideological information, so as to adopt a more targeted educational method to improve the teaching quality. For example, when some major events happen at home and abroad, the teacher can predict in time that the students' thoughts and behaviours will fluctuate. For instance, in the "Diaoyu Island" incident, the teacher should predict that the patriotic sentiment of college students will be stimulated, and some may have irrational behaviours. At this time, teachers can discuss their patriotic sentiments 
Miao, Tao, Qi / Research on the Innovation of College Students' Ideological and Political Education based on...

with students and prevent some irrational feelings and behaviours. Effective ideological information prediction and targeted measures can produce better effects of ideological and political education.

\section{Cognitive Load Coordination Teaching}

In the process of ideological and political education, it is necessary to understand the cognitive load information of the educated, so as to effectively improve the learning efficiency of the educated. For example, when the learning materials are too complex to be taught at one time, the teacher should pay attention to the individual differences of the college students, and adopt the staged teaching method to effectively reduce the cognitive load of college students. In addition, teachers need to know in advance the understanding of new contents by students during the ideological and political education. As students accumulate more knowledge, the speed of teaching can be accelerated with the content increasingly deepened. At the same time, as the ideological and political education is relatively boring compared with other courses, teachers can continuously reduce the overall cognitive load for college students through innovative teaching methods, optimized teaching methods, and expanded teaching processes.

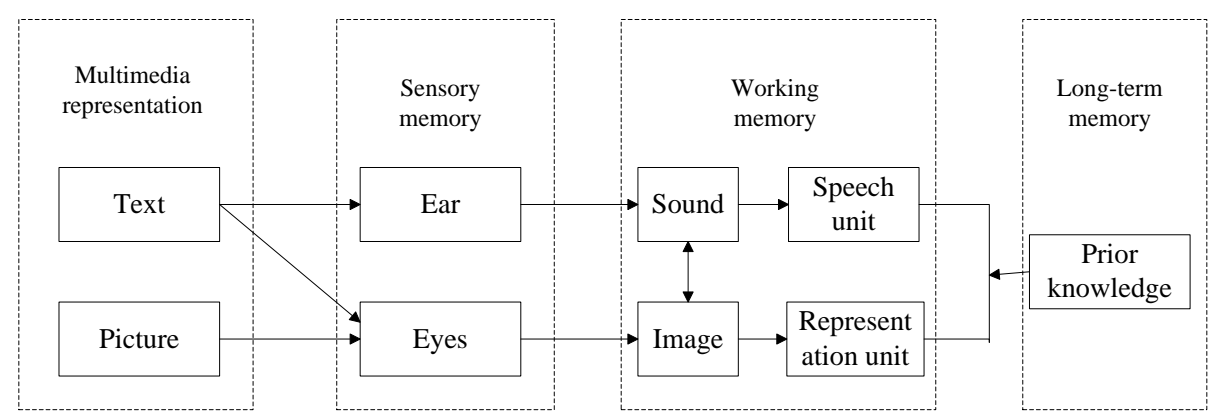

Figure 5. Multimedia teaching design of ideological and political education.

Figure 5 shows the multimedia teaching design for ideological and political education. The auditory materials and visual pictures can effectively reduce the redundant information received by students, decrease the external cognitive load of college students, and enhance the effect of ideological and political education.

\section{Ideological and Political Education Decision-making}

In the process of ideological and political education, students prefer to establish an equal communication relationship with teachers, which can easily bring the contradiction between teacher-dominance and studentinitiative. In order to ensure the orderly and smooth ideological and political education, teachers should respect students as the center of the ideological and political education, and strengthen communication with students through emotional teaching methods and talks, to develop a good teacher-student relationship and enhance the education effect. In order to achieve sound coordination between teachers and students, it is necessary to design an effective decision-making method and standardize the evaluation indicators of decision-making methods, so 
Miao, Tao, Qi / Research on the Innovation of College Students' Ideological and Political Education based on...

as to avoid the blindness and randomness of ideological and political education. The indicator system should be established in a scientific, systematic, operable, and adjustable way under the principle of democratic centralism, with the qualitative and quantitative analysis combined. The evaluation indicators can be determined by the expert selection method. The specific process is shown in Figure 6.

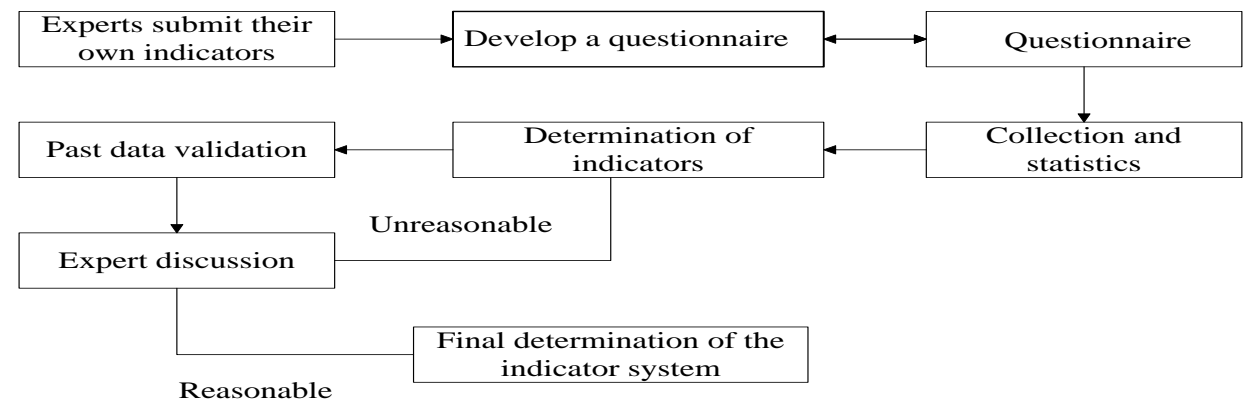

Figure 6. The process of establishing the index system of ideological and political education.

Firstly, different experts submitted their own plans. After the summary, the duplicated parts were removed. Then the questionnaire was formulated to distribute to the respondents of this survey. Based on the feedback statistics, the indicator system was initialized. After the assessment and review by experts, the final indicator system was established.

\section{Feedback on the Implementation of Ideological and Political Education}

As for the ideological and political education, implementation and feedback are the most important parts. Because the effects of ideological internalization and behavioral externalization of students and whether the purpose of ideological and political education is fully realized can be reflected in the feedback so as to guide the next step for the ideological and political education.

The more energy and resources invested in ideological and political education, the sooner the problem will be discovered so that suggestions for improvement can be put forward. However, without enough cognition, the feedback may be poor. Figure 7 shows the basic principle of the feedback mechanism of the ideological and political education approaches.

Negative feedback

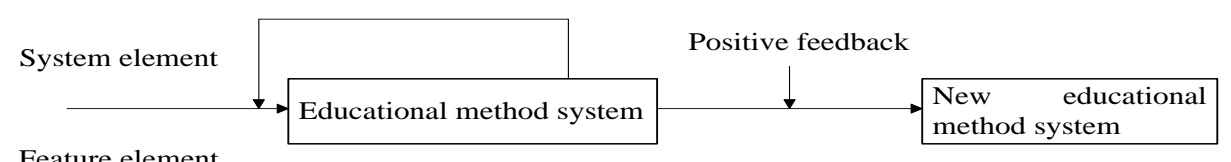

Property creation

Figure 7. The basic principle of the feedback mechanism of ideological and political education methods. 
Miao, Tao, Qi / Research on the Innovation of College Students' Ideological and Political Education based on...

During the ideological and political education, the role of feedback should be given full play to stimulate students' learning motivation, and a system of key performance indicators should be established to ensure the smooth and successful ideological and political education as required. Tables 1 and 2 display the performance appraisal system for ideological and political teachers in a university.

Table 1

Key Performance Indicator System of a University's Teachers

\begin{tabular}{|c|c|c|}
\hline \multirow{2}{*}{$\begin{array}{l}\text { Performance } \\
\text { variable } \\
\text { dimension }\end{array}$} & \multicolumn{2}{|l|}{ Key performance indicator dimension } \\
\hline & Measurement object & Performance target \\
\hline Time (100) & Ability to complete work on time(100) & Complete work efficiency \\
\hline Cost (100) & $\begin{array}{l}\text { Teacher team construction funding }(60) \\
\text { Student work expenses }(40)\end{array}$ & Cost rate \\
\hline Quality (100) & $\begin{array}{l}\text { Student evaluation(15) } \\
\text { Peer evaluation(15) } \\
\text { Supervisor evaluation(30) } \\
\text { Self-evaluation(10) } \\
\text { Awards(30) }\end{array}$ & Satisfaction rate \\
\hline Quantity (100) & $\begin{array}{l}\text { Ideological and political education } \\
\text { work(40) } \\
\text { Daily life management(40) } \\
\text { Learning management(20) }\end{array}$ & $\begin{array}{l}\text { Qualitative and quantitative } \\
\text { indicators }\end{array}$ \\
\hline
\end{tabular}

Table 2

Teacher's Key Performance Evaluation Work Index Refinement

\begin{tabular}{ll}
\hline Primary indicators & \multicolumn{1}{c}{ Secondary indicators } \\
\hline \multirow{3}{*}{ Student evaluation } & Work style \\
& Work attitude \\
& Work effect \\
\hline \multirow{3}{*}{ Peer evaluation } & Work style \\
& Work attitude \\
& Work quality \\
\hline & Organize students to participate in ideological and political education \\
& activities and theoretical study \\
& Pay attention to student party and group work \\
Ideological and political & Encourage students to participate in social practice \\
education work & Master the mindset of students and often conduct individual \\
& conversations \\
& Organize various ideological education activities \\
\hline
\end{tabular}

\section{Conclusion}

This paper, mainly based on the synergetics theory, studied the innovation of ideological and political education for college students in China, with the following concluded:

(1) Through the analysis of the status quo of ideological and political education in China, it is found that the ideological and political education of college students is challenged by problems such as belief diversification, differentiated values, and lack of collective consciousness. 
Miao, Tao, Qi / Research on the Innovation of College Students' Ideological and Political Education based on...

(2) This paper, based on the basic methods in the synergetics theory, established an innovative model of ideological and political education, namely the open synergistic teaching method, including the ideological information forecasting method, cognitive load coordination teaching method, ideological and political education decision-making method, and ideological and political education implementation feedback method, which can be applied universally.

\section{References}

Carbonaro, B., \& Serra, N. (2002). Towards mathematical models in psychology: A stochastic description of human feelings. Mathematical Models \& Methods in Applied Sciences, 12(10), 1453-1490. http://dx.doi. org/10.1142/s0218202502002197

Engelen, A., \& Brettel, M. (2012). A coalitional perspective on the role of the R\&D department within the organization. Journal of Product Innovation Management, 29(3), 489-505. http://dx.doi. org/10.1111/j.1540-5885.2012.00919.x

Gagnon, M. P., Ouimet, M., Godin, G., Rousseau, M., Labrecque, M., \& Leduc, Y., Abdeljelil, B.A. (2010). Multi-level analysis of electronic health record adoption by health care professionals: A study protocol. Implementation Science, 5(1), 30. http://dx.doi. org/10.1186/1748-5908-5-30

Giunta, C. J. (2014). Review of teaching the nature of science: Perspectives and resources. Journal of Chemical Education, 91(1), 15-16. http://dx.doi. org/10.1021/ed400810p

Higgs, E. J. (1996). The statistical big bang of 1911: Ideology, technological innovation and the production of medical statistics. Social History of Medicine, 9(3), 409-426. http://dx.doi. org/10.1093/shm/9.3.409

Hu, M. C. (2011). Evolution of knowledge creation and diffusion: the revisit of Taiwan's Hsinchu science park. Scientometrics, 88(3), 949-977. http://dx.doi. org/10.1007/s11192-011-0427-5

Keskimäki, I. (2008). Eupha president's column: Equity, solidarity and Eupha. European Journal of Public Health, (2), 212-213. http://dx.doi. org/10.1093/eurpub/ckn003

Paton, C. (2012). Competition and integration: the NHS future forum's confused consensus. British Journal of General Practice, 62(596), 116-117. http://dx.doi. org/10.3399/bjgp12x625355

Radek, Č. (2014). Language and ideology: Quantitative thematic analysis of new year speeches given by Czechoslovak and Czech presidents (1949-2011). Quality \& Quantity, 48(2), 899-910. http://dx.doi. org/10.1007/s11135-012-9811-3

Somerville, R. C. J. (2014). Is learning about climate change like having a colonoscopy. Earths Future, 2(2), 119-121. http://dx.doi. org/10.1002/2013ef000169 